\title{
The Castrum Novum project: history and archaeology of a Roman colony (Santa Marinella, Rome, Italy)
}

\author{
Luca Desibio ${ }^{1,}$, , Flavio Enei ${ }^{2}$, Sara Nardi Combescure ${ }^{3}$, Gregoire Poccardi ${ }^{4}$, Viviana Sia ${ }^{5}$, \\ Maria Teresa Levanto 5 , Alessandra Squaglia ${ }^{5}$ \\ ${ }^{1}$ Università degli Studi Roma Tre, Lettere e Filosofia, Rome - Italy \\ ${ }^{2}$ Museo del Mare e della Navigazione Antica, Castello di Santa Severa, 00058 S. Severa (Rome - Italy) \\ ${ }^{3}$ Université de Picardie Jules Verne, Centre de recherche en art, Chemin du Thil, 80000, Amiens, France, UMR 8546, CNRS-ENS, Paris, \\ France \\ ${ }^{4}$ Université de Lille 3 - Charles-de-Gaulle, HALMA-IPEL - UMR 8164 (CNRS, Lille 3, MCC), Domaine universitaire du "Pont de Bois", \\ Rue du Barreau BP 60149 ,F - 59653 Villeneuve d'Ascq Cedex (France) \\ ${ }^{5}$ Freelance Archaeologist, Rome, Italy
}

\section{Email address:}

lucarcheo@gmail.com (L. Desibio), muspyrgi@tiscali.it (F. Enei), saracombescure@free.fr (S. Nardi), grpoc@yahoo.fr (G. Poccardi), viviana.sia@gmail.com (V. Sia), mariateresa.levanto@libero.it (M.T. Levanto), alessandra.squaglia@alice.it (A. Squaglia)

\section{To cite this article:}

Luca Desibio, Flavio Enei, Sara Nardi Combescure, Gregoire Poccardi, Viviana Sia, Maria Teresa Levanto, Alessandra Squaglia. The Castrum Novum Project: History and Archaeology of a Roman Colony (Santa Marinella, Rome, Italy). International Journal of Archaeology. Special Issue: Archaeological Sciences. Vol. 3, No. 1-1, 2015, pp. 62-75. doi: 10.11648/j.ija.s.2015030101.18

\begin{abstract}
The French-Italian archaeological project born in 2010 is detecting the ancient ruins of the roman colony of Castrum Novum. Since 2010, the archaeological research has concentrated on the remains of a balneum and the so-called "squared building", probably two structures located in the extra-urban area. The archaeological reports about those areas have showed a long continuity of use until the $3^{\text {rd }}$ century AD. During last year (2014) the archaeological campaign has involved also the hill where previous magnetometric survey revealed the traces of building and squared structures. It is probable that the ruins of the ancient city lie under the hill.
\end{abstract}

Keywords: Castrum Novum, Colony, Squared building, balneum, Torre Chiaruccia

\section{Introduction}

The archaeological site of Castrum Novum lies on a wide area facing the sea, at the $64.4 \mathrm{~km}$ of the Aurelia State Road. We are in the Province of Rome, in a territory corresponding to today's Santa Marinella, which, during the Roman ages, belonged to Caere, now Cerveteri. The Roman colony of Castrum Novum, deducted at the first half of the third century $\mathrm{BC}$, was one of the most important cities found along the ancient etruscan coast as Alsium (now Palo Laziale) and Pyrgi (Santa Severa) (Fig. 1). Nowadays the ruins of the ancient Castrum Novum, are located between Torre Chiaruccia and Casale Alibrandi. Other significant remains, concerning the ancient city and the ancient harbor, lie close to the beach where now some modern stilts stand.

Whereas under the uncultivated promontory, before the old entrance of Casale Alibrandi, is located (with great probability) the hearth of the roman colony of Castrum
Novum. Pursuant to the ancient document, such as epigraphs and the reports belonging to the first archaeological campaign occurred during the $18^{\text {th }}$ century, walls, a forum, a theatre, at least a big portico, a temple of Apollo, an archive, an aqueduct and some baths endowed the ancient city of Castrum Novum. Several documents, such as the epigraphs and the ancient writing source, let us understand something more about this ancient city although we have to record a big lack about this. In fact, in particular the ancient sources seem not so clear about which of two Castrum Novum they are talking about. In fact, the ancient source also mentions another Castrum Novum located in the ancient territory of Picenum. On our Castrum Novum, we can also count on the latest and important source of Rutilio Namaziano, dated around the year $416 \mathrm{AD}$ [1]. Leaving Rome and sailing towards the north, passing along the coast of Latium, he 
describes Castrum Novum as an abandoned city, almost destroyed with an only one city-door still working, with a statue of God Pan to "control" it. This is the last important source on Castrum Novum. After, this city will undergo a long period of oblivion.

The first time the name Castrum Novum re-appeared, was in 1624. Precisely it is mentioned within the second volume of Italia Antiqua wrote by Philip Clüver, where the author, identified the site of the roman colony with the ruins that surfaced by the sea near Capo Linaro. [2].

In 1630, during the travel from Paris to Rome, the French writer Jean Jaques Bouchard during a stop near Santa Marinella, wrote that Cluverius had identified Castrum Novum in that place four miles from Civitavecchia [3].

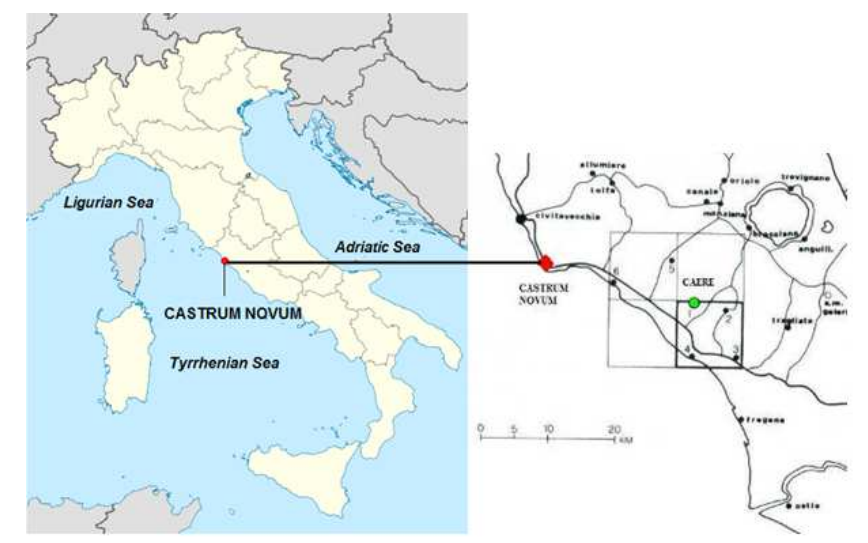

Figure 1. The localization of Castrum Novum in Italy with a detail of the ancient settlements.

However, it will be only through 1776 and 1779 that will take place the first archaeological excavations on Castrum Novum. Those campaigns had been purposed by, at that time, Pope Pio VI, in an unknown point of "Tenuta Camerale della Chiaruccia"[4]. During the 1795-96, two dig campaigns occurred: the first one of them took place at "Torre Chiaruccia" after the discovery of an ancient Roman Way (may be the ancient via Aurelia), whereas, the second one, conducted by Giuseppe Alibrandi in his property, brought to light an acephalous draped statue [4]. In particular, during the last digging campaign, several rooms with mosaic had come to light along the beach and signaled in a manuscript wrote by the archpriest Francesco Tofani [4]. Through 1829 and 1840 , we have information about an archaeological campaign conducted by Pietro and Lorenzo Alibrandi and in 1840 the archaeological activity conducted by the duchess of Sermoneta, led to the discovery of an Etruscan necropolis into the area named Guardiole [4]. Other archaeological campaigns took place during the $19^{\text {th }}$ century: Alibrandi Valentini, already in the area of Guardiole, conducted the last one of them where came to light a portico linked to several rooms, some of which contained mosaic floor. Through 1917 and 1940, we have only some information about surveys led by Salvatore Bastianelli. The last research goes back to 1970 , managed by the "Soprintendenza per $i$ Beni Archeologici dell'Etruria Meridionale", into the area near Casale Alibrandi. In that occasion, it was a preventive archaeology dig, caused by a project of new buildings. In that circumstance several structures are brought to the light, at that time well documented and which the French-Italian archaeological project today has been concentrating on.

\section{The International Archaeological Project}

The international archaeological project of Castrum Novum began in September 2010. It is a French-Italian project, which aims are the study and the re-discovery of an important Roman colony and a Tyrrhenian port of call. This project, supported by the initiative of the Municipal Museum of Santa Marinella (Museo del Mare e della Navigazione Antica di Santa Severa), has been possible thanks to the closer collaboration between French and Italian institutions: Soprintendenza Archeologica per l'Etruria Meridionale, Université de Picardie Jules Verne, Université de Lille 3 Charles-de-Gaulle, UMR 8546 of CNRS - AOROC of École Normale Supérieure of Paris, the Municipality of Santa Marinella and the Association "Gruppo Archeologico del Territorio Cerite" with its "Centro Studi Marittimi".

As mentioned above, the most recent archaeological campaign on this area goes back to the 1970 when, the Soprintendenza Archeologica per l'Etruria Meridionale conducted some preventive archaeological excavations for the construction of several residential buildings. This activity produced the publication of reports about the archaeological evaluation and excavation, edited by Piero Alfredo Gianfrotta and carried out in 1972 (Formae Italiae) [5]. With this paper we want to expose some important results regarding the last archaeological campaigns particularly conducted over three different zones and sectors occupied by a balneum (Zone A sector I), the squared building (Zone A sector II) and the coast (Zone B).

\section{The Archaeological Evidence}

\subsection{The Balneum}

The first step, conducted over this site since September 2010 , was to clean the area by the rubbish and to realize a preliminary survey drawing the structures.

With the aid of the previous archaeological reports and the new archaeological activity, it was clearly possible to recognize seven rooms: the first one (Room 1), not visible at the present, preserves the rest of a mosaic of black and white tesserae, while the Room 2 shows, just in situ, a bath feeding by a canal, covered by cocciopesto.

The Room 3 corresponds to an hypocaustum, of which some traces are already recognizable. Some doubts emerged for the Room 4 which, probably, belongs to a later phase after the abandon of the balneum and which seems to reuse materials coming from the previous structures.

Despite the foundation of this area seems so well preserved, we can observe a lack of any traces of floor and it 
is likely that, it was just on beaten earth. The nearest latrine (forica, Room 5) already preserves an opus spicatum flooring surrounded by a drainage duct. Lying on a lower level, we have the rest of two rooms (6 and 7$)$, which were originally unified. One important archaeological evidence in this area is represented by the discovery of two praefurnia heating the Room 3 and 8. The Room 8, probably, should correspond to the calidarium of the balneum, provided of an hypocaustum with the walls warmed by several pipes for the passage of warm air.

\subsection{A Preliminary Analysis on the Balneum Walls}

With regard to the study of the monument, it seemed useful to propose a synoptic and comparative analysis of the data obtainable from the previous one and from the recent data capture. The ruins of balneum are divided into different rooms oriented NE-SW. A comparison of the thermal building plans, published respectively in 1972 and 2013 allows us to clarify which areas of the building have been brought to light by recent excavations (Fig. 2)

The structures examined were considered by previous studies as part of a seaside villa, located along the seashore, which is equivalent of some fish-ponds still visible [5].

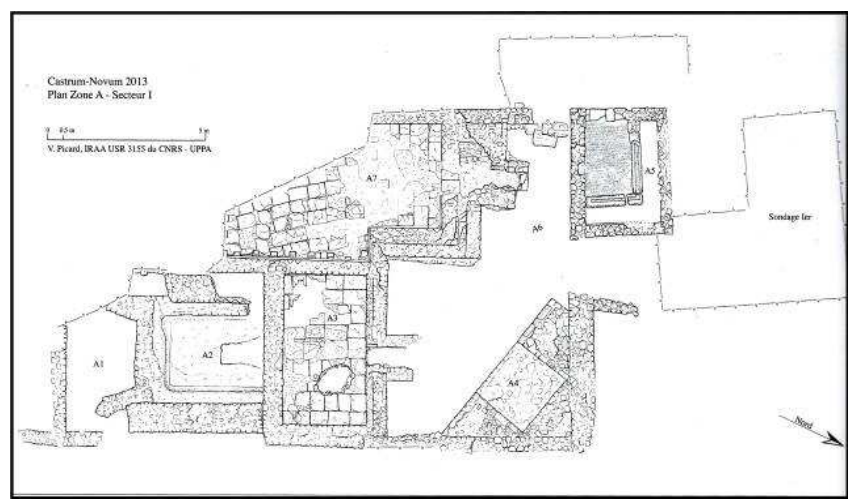

Figure 2. Guardiole Villa: balneum plan

Two main phases of construction were identified, attributable respectively to the end of the $1^{\text {st }}$ century $\mathrm{BC}$ - early $1^{\text {st }}$ century $\mathrm{AD}$ and the second half of the $1^{\text {st }}$ century AD [5]. Starting from the south area, the room cited by Gianfrotta, has not been completely digged and therefore not shown in the plan of 2013. The archeologist described the presence of traces of a mosaic pavement with black and white tesserae, resting on the slab of stone chips and fragments of bricks associated with lime [5]. The Room 1 (Fig. 3) in September 2013, revealed a filling consisting of large shapeless stones presumably connected to a second phase of balneum, characterized by the cutting of the frigidarium bath and by the obstruction of the duct water supply. The opus signinum bath referred to Room 2 (Fig. 4) in the publication of 1972 showed at the bottom break, which is equivalent of the wall 5 at first, interpreted as a pit of illegal dispossession. Surveys, conducted in September 2013, instead revealed the existence of a hydraulic duct obliterated by large boulders of local stone. The discovery of a brick still in place inside the pipe with the seal Aprilis CN (aei) DOMIT (s) dated $120 \mathrm{AD}$, is surely a terminus post quem for the construction of the duct and the hydraulic bath [6].

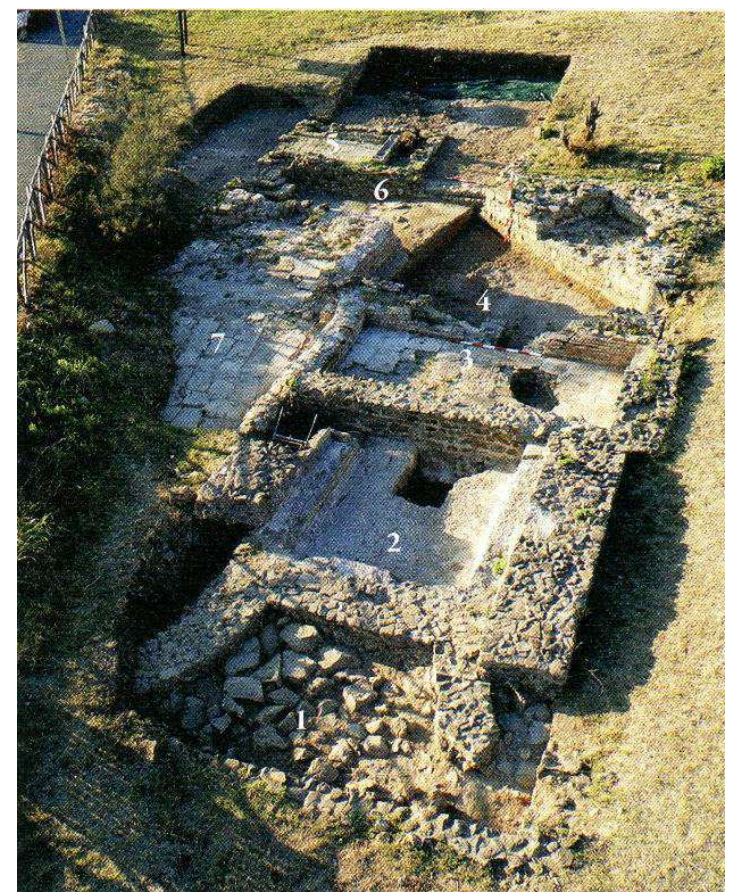

Figure 3. Guardiole Villa: balneum rooms

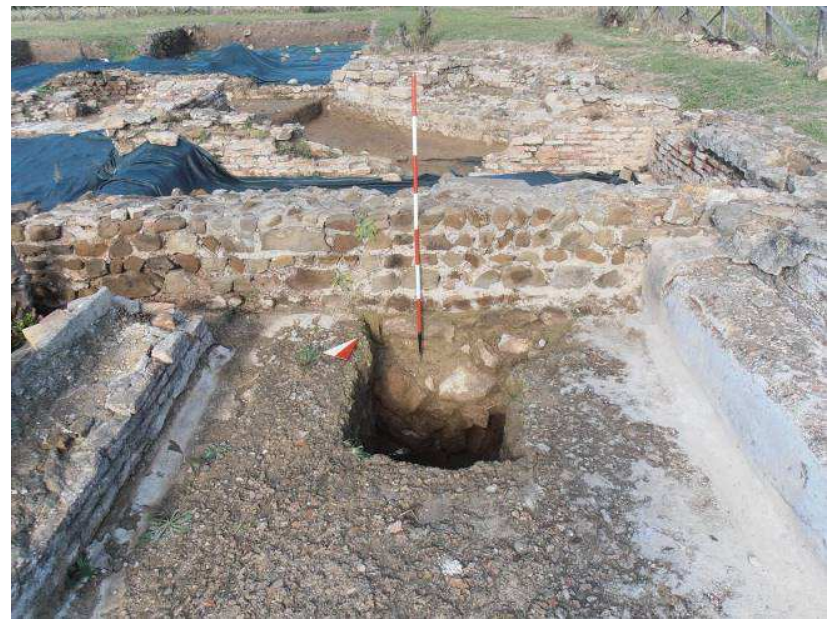

Figure 4. Guardiole Villa: frigidarium bath

At the time of the duct occlusion, the bath was cut by the construction of the wall 5 , which also eliminated a drainage made of concrete ground for the outflow of water. Adjacent to the bath there are two different sized rooms (3 and 7) which retained in 1970 some suspensurae built by bessali, originally high about $0.50 \mathrm{~m}$, and along the walls some terracotta tubuli for the passage of warm air [5]-[6]. Both rooms were the hypocaust cavity. The internal walls of the Rooms 3 and 7 appear covered with bricks and tiles in regular rows. Two other areas, located in the north, originally communicating each other and located in a slightly lower level than the rooms with suspensurae, were provided by two prefurnia, of which the Room 7 in 1970 still had the bow brick [5]. The rooms with 
suspensurae and praefurnia have a structure built at the same time. The Room 3 is bounded by the walls Nos. 5, 6, 7, 8, 9 . The facings of the walls No. 8 and 9 (MSU 6) appear as an opus mixtum framed by square blocks of stones and tiles (Fig. 5) [6]. The second room with hypocaust (Room 7) has walls made of tiles and bricks arranged in regular rows; both rooms have a floor composed of rectangular tiles joined by a light gray mortar [6]. These two rooms, likely treated as a tepidarium (Room 3?) and caldarium (Room 7?) should have been connected to a frigidarium, identified with the bath in opus signinum analyzed before.

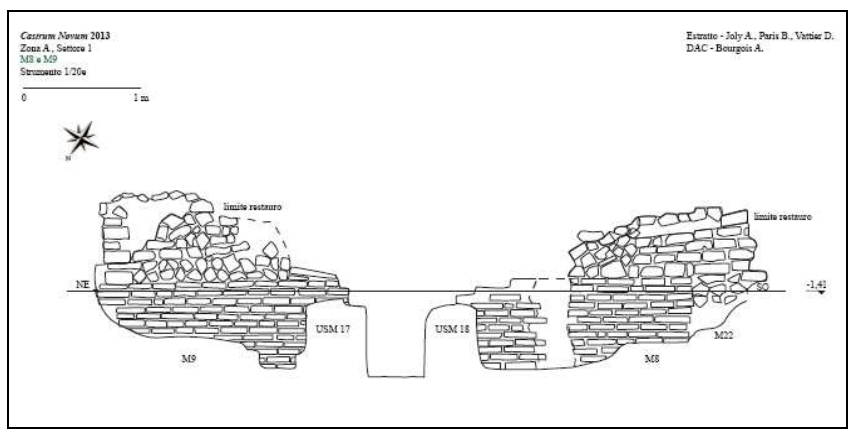

Figure 5. Wall of the rooms $8-9$

The logical observation from which comes out the identification of the three rooms of the villa, with those ones reserved for a spa bath, clashes with the interruption of the frigidarium bath by the wall No. 5 of the room with suspensurae (Room 3). The interruption of the use of the pool, based on archaeological data available to us, would seem to be placed no later than the end of the $3^{\text {rd }}$ century $\mathrm{AD}$, a time in which the Rooms 3 and 7 should have been built. Even though the existence of two phases of construction of the supposed thermal building is admitted, (dating back respectively to the $1^{\text {st }}-2^{\text {nd }}$ century and the $3^{\text {rd }}$ century AD), it remains to be explained the cut of the bath, the supposed frigidarium, the duct and the southern part of the structure obliteration by the aforementioned filling of large blocks. It could be considered the reconstruction of a new bath in another area of the building and not investigated yet. To the north of these areas a forica (Room 5) was brought to light as early as 1970 [5] - [6]. The room is still in good condition. The perimeter walls consist of local limestone rags, the opus spicatum floor framed by a channel covered by opus signinum. According to the data relating to the excavation of 1970, the entire area was covered by an archaeological layer dating to the early decades of the second century and material subsequent to that period was not found either sporadically [5]. That statement, which is considered likely to have variations by Gianfrotta who had made it, it can be reviewed today according to the preliminary studies carried out on material found during the excavation campaigns 2010-2013, which document that the spa baths had been attended since the Augustan period until the $3^{\text {rd }}$ century $\mathrm{AD}$ [6]. The excavations in 1970 brought to light the ruins of a room (Room 4), not analyzed by Gianfrotta but detected in the general plan drawn up at the time of the excavation (Fig. 6).

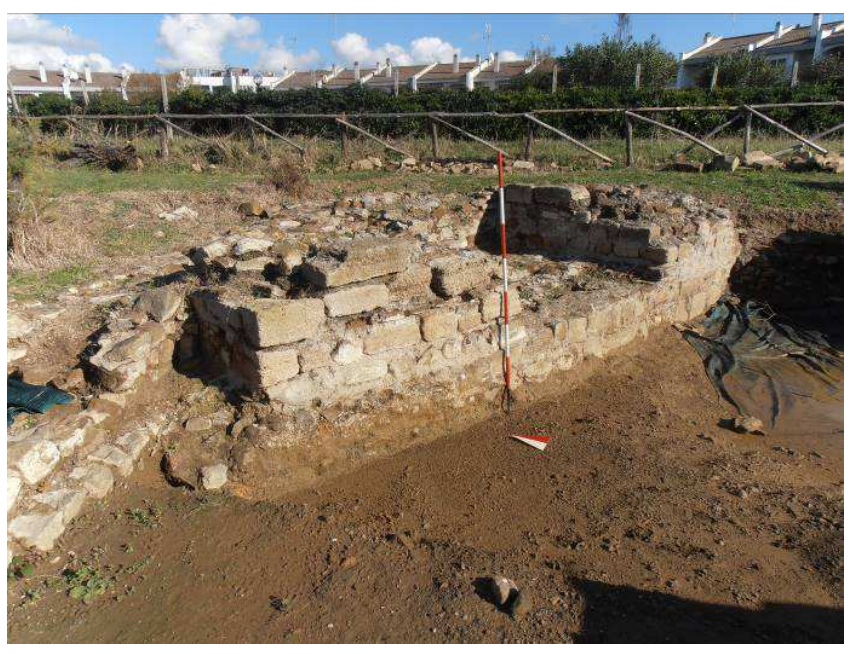

Figure 6. Guardiole Villa: Room 4

The room is set in a corner of the balneum and it has a triangular shape. It is a cement structure, oriented towards the North and the South with opening to South, whose wall curtain is made of blocks of local stone called "scaglia", rags of local limestone and re-used tiles arranged on regular rows. It is supposed that the room, whose function is still not determined, dates back to the late phase of the thermal building probably coinciding with its abandonment [6]. Recovery materials coming from balneum could be traced back to its construction at a time when the structure was still visible but no longer used [6]. The structure oriented towards the diverticulum of the ancient Via Aurelia may be referred to a fortification, perhaps a turret dated between the $5^{\text {th }}$ or $6^{\text {th }}$ and $8^{\text {th }}$ centuries AD [7]-[8], historical period that saw the decline of Castrum Novum as a coastal town during the Greek-gothic wars and the barbarian invasions [9]-[10]-[11]. The Guardiole, the name of that area, could be connected to the presence of a defense and sighting structure. In fact, the name could come from the Lombard warda which means "place of observation," "guard station" [6].

\subsection{Pottery and Other Archaeological Finds from the Balneum}

Several types of finds have been catalogued during the excavations of this site in recent years (2010-2013).

The most ancient type of pottery here discovered belongs to the black varnish ware $\left(2^{\text {nd }}-1^{\text {st }}\right.$ century BC).

The coarse ware seems to be represented by numerous fragments. One of these belongs to an edge of olla dated between the $1^{\text {st }}$ and $2^{\text {nd }}$ half of $2^{\text {nd }}$ century $\mathrm{BC}$ and another one dated, more precisely, between 120 and $140 \mathrm{AD}$, both discovered within the Room 3, identified as a tepidarium [4]-[6].

From the SU 111, located among the Rooms 4, 6 and 3, comes an edge of olla dated between $1^{\text {st }}$ and $2^{\text {nd }}$ century AD. The italic and late-italic terra sigillata class pottery appears less representatives with regard to its amount, but quite interesting for its quality. They are two fragments belonging to a cup with an interesting external decoration representing a 
human figure and a stamp on the base (Fig. 7); another fragment presents a decoration with acanthus volutes. During the latest excavation campaign have been discovered here several little amphorae or "amphoriskoi" dated during the $1^{\text {st }}-2^{\text {nd }}$ century $\mathrm{AD}$ and which the real original use seems today already discussed [6]. The most relevant quantity of pottery here found belongs to the class of African cooking ware, known as "patina cenerognola". Within the new layers the presence of this kind of ware is revealed by the finding of several fragments belonging to the form of casserole (Ostia III, 6), dated between the first half of $2^{\text {nd }}$ century and the end of $4^{\text {th }}$ century AD. Others fragments belong to the form of dish-lid (Ostia I, 3, 7) in use from the $2^{\text {nd }}$ century to the $4^{\text {th }}-5^{\text {th }}$ century AD [13].

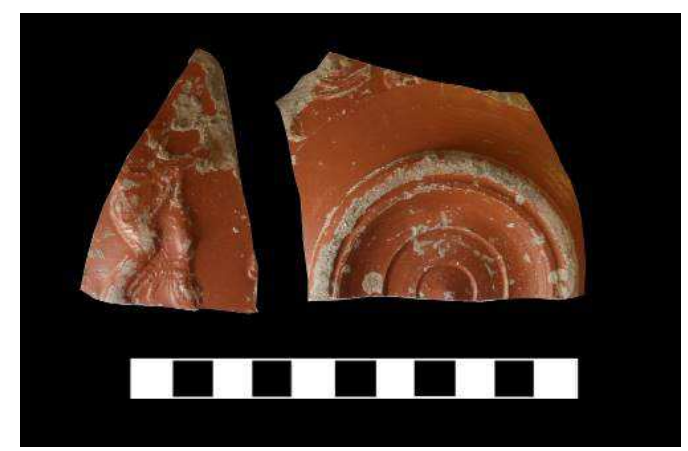

Figure 7. Terra Sigillata, decoration with human figure

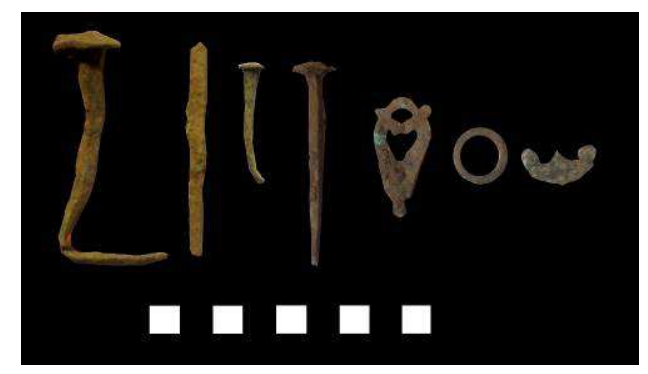

Figure 8. Metal findings

This class of pottery actually represents the latest testimony of use in this area. Before closing this framework, it is interesting to point out the finding of a rectangular stamp on a tile $(\mathrm{cm} 10 \times 4$; h. letter $\mathrm{cm} \mathrm{2,3)} \mathrm{containing} \mathrm{the}$ inscription C.EREN.C [...] dated to the late Republican Period. To conclude this context we want to signal the finding of a big fragment of a dolium's rim discovered within the new trench, opened on the northeast side of the balneum. During the excavation of this trench came to light a bronze brooch (SU 118), bronze rivets of several dimensions and a lead fragments, probably belonging to a fistula, and another object catalogued in general terms as pendant (Fig. 8). The archaeological evidence seems to suggest a continuity of use of these structures together identified as a balneum. This building at least from the $2^{\text {nd }}$ century $\mathrm{BC}$ could reach to the beginning of $4^{\text {th }}$ century $\mathrm{AD}$. However it seems possible to bring back the chronology to the $3^{\text {rd }}$ or $2^{\text {nd }}$ century $A D$, according to Gianfrotta's archaeological report [5] and if we consider the earliest phase of production of the African cooking ware (a patina cenerognola) (Ostia I; Ostia III) whose class, in this case, represent the most recent terminus we have.

\subsection{The "Amphoriskoi" of Castrum Novum: a type of pottery searching for an identity}

The pear-shaped "pots", usually known as "Amphoriskoi", were found nearby the entrance of the hypocaust (Room 3) (Nos. 2, 3, 4). A fourth "anforiskos" was found along the foundation wall (MSU 9) in the Room 4. The No. 4 comes from the SU 118 while other pots were found in a layer where there was a deposit of soil placed there after the excavation of 1970 the so-called SU 0. The No. 3 was covered by a dark coat of ash coming from the praefurnium area relating to the Room 3 , probably the tepidarium of the bath.

- Pear-shaped pot, reconstructed from two joined fragments, corresponding to the Pavolini 16b type. 2010 Excavation campaign. Zone A, Room 1, SU 0; $15 \mathrm{~cm}$ high; border diameter $6.5 \mathrm{~cm} ; 6.5 \mathrm{~cm}$ maximum expansion. Border inward and distinct from the body. Full square tip. Light beige clay, porous and friable, traces of brown engobbio. Presence of small craters and lumps of clay on the wider part of the body. Grooves on the surface. Possible traces of pitch on the mouth. (Fig. 9)

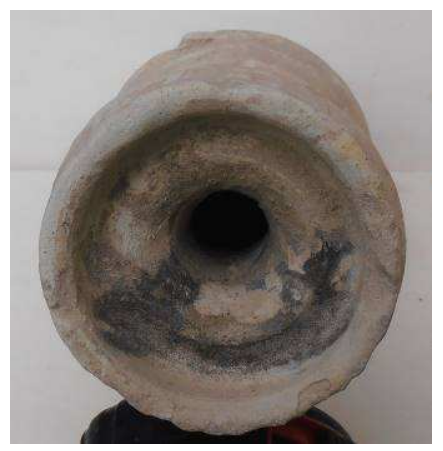

Figure 9. Amphorisko's No 1/Type $16 b$ mouth with pitch

- Pear-shaped pot Pavolini 15b type. 2011 Excavation campaign. Zone A, Room 1, SU 0; $10 \mathrm{~cm}$ high; border diameter $4.5 \mathrm{~cm} ; 4.5 \mathrm{~cm}$ maximum expansion. Border is fragmentary not distinct from the body. Pink clay. Full tip. Grooves on the surface (Fig. 10).

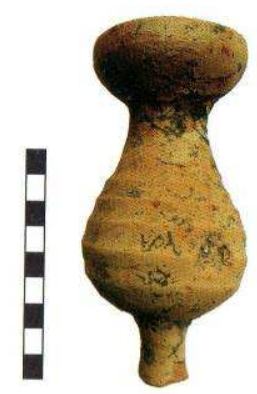

Figure 10. Amphoriskos No 2/Type $15 b$

- Pear-shaped pot Pavolini 15b type. 2011 Excavation 
campaign. Zone A, Room 1, SU 0; $7 \mathrm{~cm}$ high; $4.5 \mathrm{~cm}$ maximum expansion. With no border. Pink Clay. Full tip. Grooves on the surface (Fig. 11)

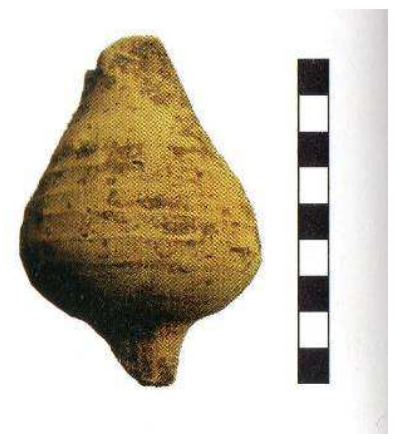

Figure 11. Amphoriskos No 3/Type 15b

- Pear-shaped and intact pot, Pavolini 15b type. 2013 Excavation. Zone A, Room 1, SU 118; $11 \mathrm{~cm}$ high; border diameter $5 \mathrm{~cm}$; maximum expansion $\mathrm{cm} \mathrm{5,3.}$ Border not distinct from the body. Light beige clay with white and mica traces. Small crater on the surface of the body. Full tip. Grooves on the surface (Fig. 12).

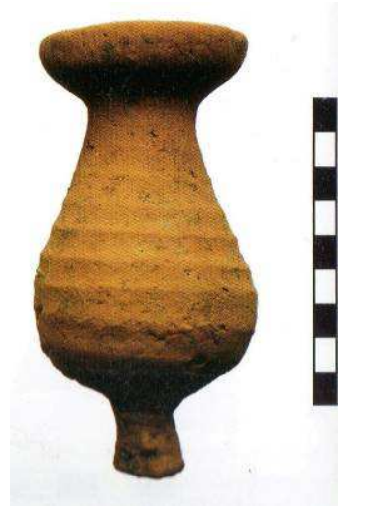

Figure 12. Amphorisco No 4/Type $15 b$

As part of the common ceramic, this particular kind of pottery does not have yet an exact classification because we do not know yet for what it was used for. The typological classification followed by these brief notes was determined by Pavolini, based on the study of ceramic objects from the Baths of the Swimmer in Ostia [14].

It is useful to summarize the most significant theories about the use of these artefacts still searching for their identity and particularly the right word indicating the reason for their genesis. According to the present study, we indicate this particular ceramic as "pottery" [14], as part of a wider production of common ceramics, along with well-defined shapes and classification. The 'pottery' is coarsely and roughly made, with an irregular and asymmetric shape, no handles, with a small and generally cylindrical tip, depriving the "pottery" to stand, a flared mouth and sometimes exaggerated. The neck presents a narrowing, often accentuated and an evident expansion in the central part of the body with spiral grooves. Therefore, that makes them similar to small amphorae and gives them the name "amphoriskoi". In the central part of the body, there are small lumps of clay and small cavities, caused by the close contact of the pottery during the drying phase. The detected height by the Ostia samples (over 300) is between 6.5 and $19.3 \mathrm{~cm}$ [14].

The great dilemma about the use of these unusual artefacts has involved a large group of researchers who have formulated theories very different from each other. The first most popular theory says that the 'pottery' was used as stopper of the amphorae, inserted upside down into cork, wooden or other material stoppers, attached to the neck of the amphora by pitch, clay or gypsum [14]. In this way the body of the amphoriskos jutting to outside, was used as a grip to pull the stopper, thanks to the grooves on its surface, too [14]. In addition, Emilio Rodriguez Almeida established a link between "pottery" and amphorae, theory which could be supported now by the author of this article after the finding of the amphoriskos 1 in Castrum Novum. According to the Spanish researcher, 'pottery' was used as suction cups or cucurbitula [15] to open the stoppers of the amphorae [15]. After spreading the mouth of the "pottery" with hot pitch, it was placed on the surface of the stopper and through the condensation of the air inside the ceramic body, a traction by suction occurred that could crumble the mortar or gypsum, which sticks the stopper to the neck of the amphora and makes it easy to open [16]. As we have already mentioned, the probable traces of pitch on the mouth of the amphoriskos No.1 of Castrum Novum could be a positive element for the Almeida's theory.

Among a range of different hypothesis about the utilization of "pottery", as laps [14], unguentaria [14]-[17], elements for building vaults [14]-[18] and unit of measure [17], the theory given by Annecchino as possible fritilli (cases for dice) [14][17], was the only one that had been sustained by an archaeological acknowledgement thanks to the discovery of a pear-shaped pottery that had a dice stuck inside the neck, found in a burial in the Roman necropolis in Bevagna [14][17]. The two hypothesis fritilli or cucurbitula, make us think. As regard to the fritilli we can not explain the reason why the neck is sometimes too narrow to let the dice outflow and, as of the hypothesis of the suction cup, that detail would not create any difficulty. Almeida of the curcubitula, could relate the finding of the pear-shaped pottery with the dice inside the neck, to a secondary use, while the presence of the pitch on the mouth of the pottery could agree with the theory, so the "pottery" could be part of the world of commerce of the amphorae. However, we cannot explain why the production of such a kind of pottery seems to stop unexpectedly at the end of the $2^{\text {nd }}$ century AD. The 'pottery' Nos. 2,3 and 4 correspond to the Pavolini type $15 \mathrm{~b}$, which, attested from the half of the $1^{\text {st }}$ century AD (in Pompeii, Albintimilium, layers of the Baths of the Swimmer - Flavian period) reveals a higher concentration in Trajan time [14].

The 'pottery' No. 1 belongs to a type that is chronologically different from the previous one. The type 16b, which our pottery can be related to, belongs to a production between the end of the $1^{\text {st }}$ and the end of the $2^{\text {nd }}$ century AD [14]. The higher occurrence of this pottery was in Hadrian time, in 
which other productions went down. Their disappearance in the Severian time [14] - [19], in recent studies, it is believed that the production of the Ostia "pottery" does not reach the end of the $2^{\text {nd }}$ century AD [14] - [19].

We do have remarkable evidence with the clay of Ostia productions. The pink clay of the types $15 \mathrm{~b}$ is close to the main types (jugs, bottles) found at the Baths of the Swimmer, dating between the Flavian and Trajan time [14]. We can assume the presence of a local production with its own shapes failing news about kilns and backlogs, because the characteristics of the clay have not been supported by the amphorae productions coming from the Empire provinces, between the $1^{\text {st }}$ and $2^{\text {nd }}$ century AD. The type $16 \mathrm{~b}$, the only "pottery" found in Castrum Novum has a different ceramic. The analysis of the Ostia "pottery" of the same kind had revealed some differences from the other types about the consistency of the clay, soft or even powdery. The Pavolini's hypothesis is that the types 16-17 are non-local and non-Italic manufacture but coming from volcanic Mediterranean areas (with the exception of North Africa) [14], highlighting in the Ostia common ceramic a large number of local and Roman Italic production [14] - [19], at least until the early decades of the $2^{\text {nd }}$ century $A D$, then replaced by artefacts imported from the provinces starting from this period [14]. The technical characteristics of the "pottery" 15b of Castrum Novum, being the same as those ones above mentioned and then related to the production areas of Latium and Rome, do not offer other considerations different from those ones indicated in the analysis about their use. On the contrary, the "pottery" 16b, maybe of provincial provenance, could be a concrete proof, an unicum, connected to the trade and the transport.

The question about this enigmatic ceramic is still open. Finally, we can validate the versatility and multifunctionality of an object that, whatever its primary use, thanks to the convenience of its shape and the resistance of the clay, could be used in everyday life [14] - [19].

\subsection{The glasses from the Balneum}

Numerous fragments attest the presence of unguentaria or toilet bottle of which two types are recognizable: those olliformi or cups and those tubular. For the first type, different pieces have been found in the SU 102 and SU 106. They belong to the form No. 44 of Isings' classification [20] (Fig. 13). From SU 102 derives a fragment of rim inclined, rounded on outside and grooved on inside, whitish color and just a little bit transparent and a fragment of rim folded and flattened on inside. Both pieces go back to the $1^{\text {st }}$ century AD. [21].

On the SU 106 three fragments of different rims were found. Although they do not belong to the same specimen, they have similar characteristics: they all have an opaque white color, but the first one has the rim inclined on outside, with folded ends, flattened to the top and cable inside. The second one and the third one instead have a rim rounded on outside. For these fragments is conceivable a chronology around the middle of the $1^{\text {st }}$ century AD.

The main difference between unguentaria and the olla form is their dimensions. In fact, the first ones are very small (10 $\mathrm{cm}$ of high maximum). Probably the use of them was domestic rather than like perfume flask.

The jar-shaped kind is different because of its dimension. It is smaller and, probably, was accustomed as a container in domestic use. We can distinguish three type of unguentaria:

1. Without neck and flattened lip;

2. Without neck and double flattened lip;

3. Inward-sloping neck, with folded tubular lip.

Sometimes they are provided of lids. We know two type of them, both at disk handles, but with different lugs, that is bottle shape or button shape [22]. In this context, fragments of tubular unguentaria are more common. In addition these toilet bottles could be of three kinds, according to the proportion between the body and the neck and very thick or medium and generally they have a soft blue color. Probably these toilet bottles with no flat bottom could have been hanged.

The tubular unguentaria were widespread in all regions of the Empire, since the $1^{\text {st }}$ to the $2^{\text {nd }}$ century $\mathrm{AD}$, mostly produced during the Flavian Age [22]-[23]-[24].

Surely, these disposable containers for essences or oil and for funeral use were very cheap. In the SU 102 were found many fragments of bowls. Particularly two basement fragments have a rounded ring and hollow base inside and yellowish - brown color [25].

Another fragment presents a decoration with a horizontal line wheel incised and in opaque white color. All the fragments probably belong to the deep bowls. These types of bowls were made in imitation of metal and pottery bowls and they were used as mixed containers, dating in the second half of the $1^{\text {st }}$ century AD. Two fragments of short handles, coming from the SU 102 and SU 106 have been identified as aryballoi. The aryballos is a common toilet bottle but it needed a triple bronze chain to hang it on. The neck is short and two short handles near the rim compose it. From the SU 102 comes the dark greenish coil handle, the other one (SU 106) is smaller than the first one and it presents a greenish light brown color. Both are comparable with the shape No. 61 of the Ising's catalogue and with the type 10 of De Tommaso's catalogue, dating to the second half of the $1^{\text {st }}$ century AD [20] - [26] (Fig. 14).

Only one fragment of beaker was found in the SU 103: it is about a foot ring base, greenish colored with a medium thickness; it could be compared to the shape No. 34 or No. 37 of the Ising's catalogue [25]

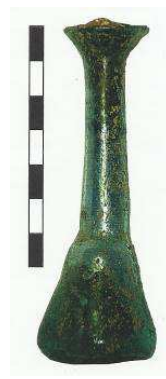

Figure 13. Unguentaria 


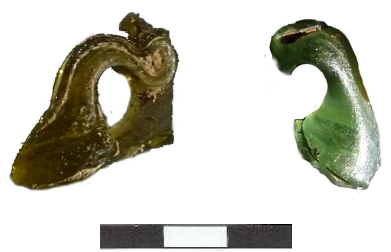

Figure 14. Handles of aryballoi found in the SU 102 and 106

The beaker could be large, medium or small size, with an ovoid, conical, cylindrical and pear shape body or often, decorated with many adornments. Most of these beakers date back the second half of the $1^{\text {st }}$ century AD.

One exemplar of the plane's fragment was identified in the SU 106. It has been recognized on a rim fragment with a wave decoration, bluish colored. It is compared to the plate preserved in the archaeological Museum of Murano, dating to the second half of $1^{\text {st }}$ century $\mathrm{AD}[21]$.

The study of these pieces, were extremely important to confirm the phases of life of the building, thanks to which it was possible dating the balneum at the $1^{\text {st }}$ century AD.

\section{The Squared Building}

In the same archaeological area, just a few meters to North-East from the balneum, lie the archaeological remains of the "squared building". This name indicates that actually do not exist any certainly proof about its function although, several years ago, it had been identified as a villa. During the first years of the archaeological campaign on this area, was used the same process of cleaning and drawing survey as that one used for the balneum.

The building edified with local stones, appears directly opened on a little street identified as the Via Aurelia Vetus. It presents a squared plane with 22 meters for each side and is orientated North-East to South-West. The main entrance was on the south-west side towards the sea. Actually, this squared building presents anomalous features to be considered a rural villa as we know in this territory or along the Tyrrhenian Etruria. However, the importance of this building seems to be confirmed by the discovery of a little private balneum on the north-west corner. A cold bath and at least a heated room without any kind of decoration or marble covering equipped this. The discovery of a kitchen seems to be very interesting. It had an instrumentum formed during the $1^{\text {st }}$ century AD with a base formed by at least four ollae and two pans.

\subsection{The Squared Building: a First Response of Reconstruction}

In agreement with the archaeological report of Gianfrotta [5], this building presents a squared plant with each side 22 meters long. In the excavation of 1970 were identified several rooms within the building: the northwest side has a heated compartment with the presence of a brick suspensurae and a mosaic floor dating back to the Augustan age. In the nearest area, the floor appears as made of small cubes of bricks [4]. Below these areas, there was a small drainage duct, probably matched with a water shaft nearby.

In the southeast area of the building three different adjacent rooms were recognized (Rooms 2-4-5). (Fig. 15).

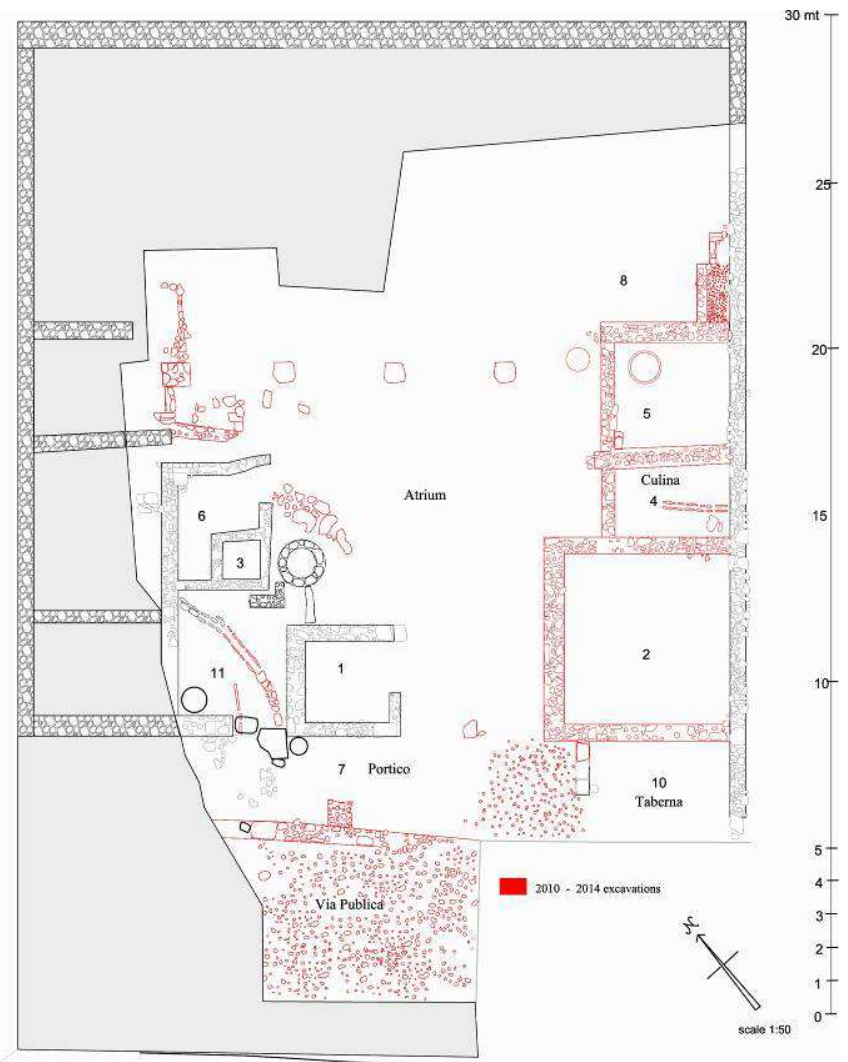

Figure 15. Plan of the last excavations from 2010 to 2014

Close to the northeast corner of the Room 5, was uncovered a base of a dolium which base was probably buried.

Another dolium, in this case larger than the external one (diameter of 1 meter), was found, just during the last archaeological campaign (2014) within the same room. In the "space" No. 8, was revealed a layer composed by bricks, shingles and tiles. This disposition suggests the layer could have been a rough floor (at least in a second time) then a collapse of structures; however, just on the north-east corner of the Room 5 was found a small rectangular structure which was identified as a tank for gather water made of a "cocciopesto" covering.

\subsubsection{The Reconstructive Hypothesis}

Observing the plan of our building seems possible to find several features comparable with those ones of the domus italica. In fact, the "squared building" like the typical domus italica appears characterized by an open - air atrium with several rooms surrounding it. On the back of this kind of domus there was usually a rectangular private garden (the hortus) [27], which, in our case, could be identified with the space No. 8. Looking at the plan, the Room 2-4-5 (the east wing) are very similar to the cubicula looking at the atrium of a domus italica. The opposite wing of the house could correspond instead (in part) to the Room 1 and 11. 
On the backyard was found a foundation of pillar that could be connected with a portico opened on the hortus. If this hypothesis is correct, the Room 12-13-14 will probably correspond to a second phase of the building.

Along the ancient road likely identified as the ancient via Aurelia, was discovered a layer with fragments of shingles and tiles that has suggested the presence of a roof belonging to some structure faced on the street (Fig. 16).

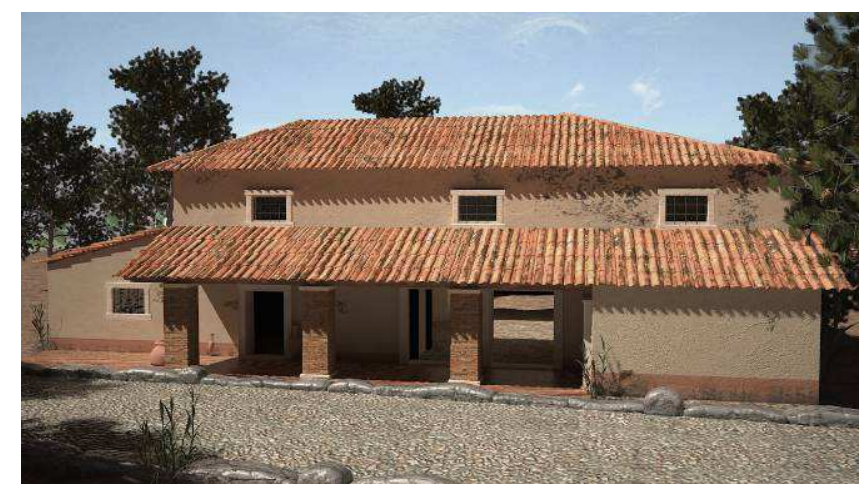

Figure 16. A frontal reconstruction of the square building.

In this area, especially near the threshold, many coins were found and that makes us think about some possible kind of trade (Fig. 19); this hypothesis with the finding of numerous coins could suggest in this area the presence of a wood floor where the coins could have got lost [6]. In conclusion, we have to signal, on the west wing of the southern portico, just in front of the threshold of the Room 11, the discovery of the base of another dolium and an amphora. (Fig. 17).

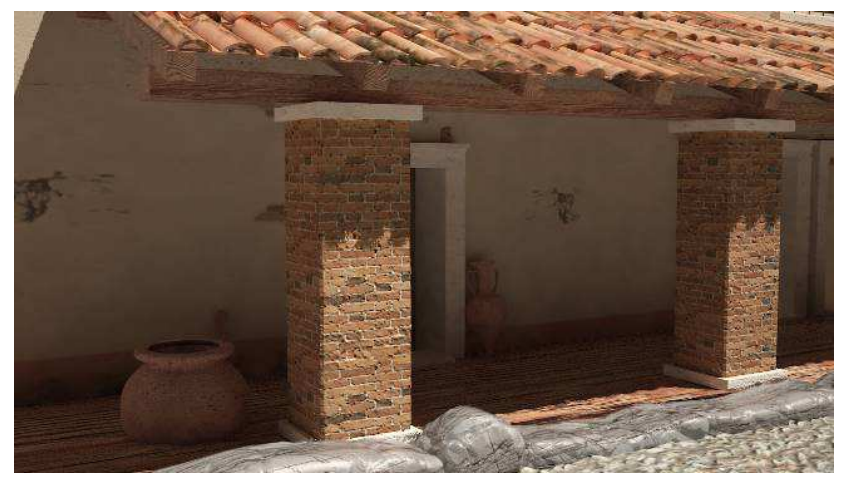

Figure 17. Particular of the frontal view

\subsection{Pottery and Other Finds from the "Squared Building"}

The analysis of the uncovered archaeological material indicates a continuous use of these structures from the $3^{\text {rd }}$ century $\mathrm{BC}$ to the $3^{\text {rd }}$ century $\mathrm{AD}$. The most ancient testimony is represented by a few fragments of bucchero blended in the ground, but their finding, likely, could be the consequence of their reuse. In fact, we have to remember that at least the first archaeological campaign had the aim to find the layers belonging to the last archaeological activity (1970). The black varnish ware is represented by several fragments among which it is possible to distinguish a little rim of cup comparable with a form dated to the second half of $3^{\text {rd }}$ century $\mathrm{BC}$ and the rim of little cup generically dated to the $2^{\text {nd }}$ century BC [28].

Coarse ware seems well represented by several fragments from the Area 7 and 11, adjoining and separated only by masonry, come most of the coarse ware fragments.

Particularly from the Area 7 come two fragments of dish-lid comparable with the type Gabii 1, dated between the end of $3^{\text {rd }}$ century and the $1^{\text {st }}$ century $\mathrm{BC}$, and a rim of late-Republican olla [15].

The Area 7 is also the place from which comes a pot's fragment, dated to the Augustan age in use until the Empire of Trajan. The Area 11 has given a pan's fragment similar and comparable with the type Sutri $2\left(2^{\text {nd }}\right.$ century BC) [15] and a rim with handle belonging to a jug of $2^{\text {nd }}$ century $B C$. Two little fragments both dated around the $1^{\text {st }}$ century AD represent the italic sigillata ware category here. As the coarse ware, also the African cooking ware (patina cenerognola) seems well represented by numerous fragments belonging to the form of dish-lid and casserole (Area 7 and 8). The SU 8 that lies to the northeast side of the squared building presents an irregular surface formed by numerous fragments of several components: pottery, bricks, tiles, stone and soil. Among those, we have to signal a handle of an amphora type Dressel 20 and the lower part of a stamp on tile with the inscription [ex] FIG.CAES [---] (Fig. 18). The formation of this area seems due to a wall collapse after which, the area could have been abandoned or reused as a stable. About the metallic finding, we can generally remember the discovery of several bronze rings and iron nails (Fig. 19). Numerous black and white tesserae of mosaic were found in the Area 7 and 11. It is likely they belonged to that mosaic pavement supported by suspensurae brought to light during the archaeological campaign of 1970. In fact the archaeological campaign of 2013 finally found the trace of that mosaic of which remains only a little slide because the rest of it was destroyed by the construction of a little street. The oldest archaeological excavations also revealed the presence of a lead fistula; also, in this case, during the most recent archaeological campaign the archaeologists found a second piece of it below the masonry that divided the Area 7 and 11 . This briefly array of archaeological materials can finish pointing out a particular and interesting discovery occurred during one of the first archaeological campaign (2011). It is a big marble object with a long side measuring $25 \mathrm{~cm}$ with only a smooth surface and an irregular side (Fig. 20). The analysis of archaeological material here discovered seems to confirm a continuous use of these structures for at least six centuries. Based on the particular concentration of several archaeological fragments and their dating, it is likely that some rooms of this structure had a different use through the centuries. Particularly we can conjecture the abandon of some areas yet after the $2^{\text {nd }}-3^{\text {rd }}$ century AD. This hypothesis seems to be confirmed by the discovery of several coins. It was especially observed that most of the Late-Roman coins was uncovered along the southern wing of the building [6]. This side was directly linked to the street and it is likely that, during one of the several change of use of this building, only 
this area continued to be used while the north side could be in abandon or used as stable [6].

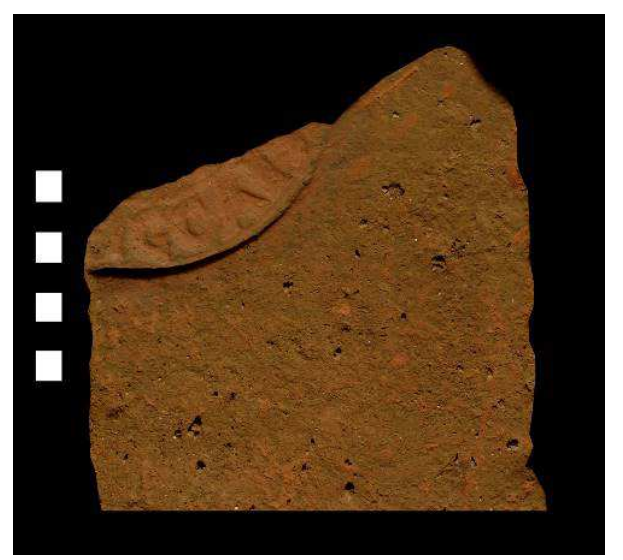

Figure 18. Fragment of brick with the stamp [ex] FIG. CAES [---].

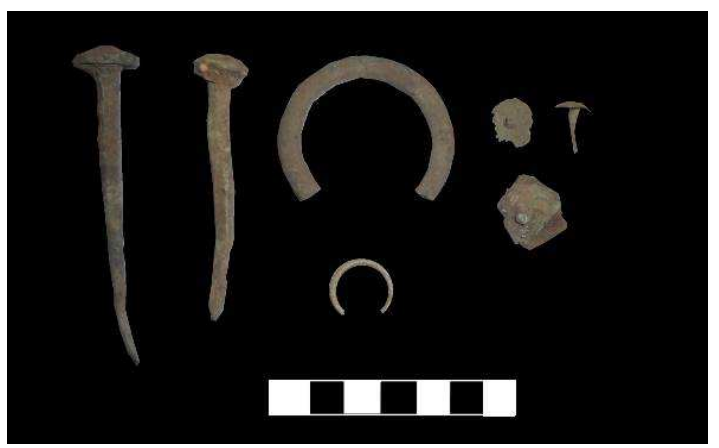

Figure 19. Metal findings

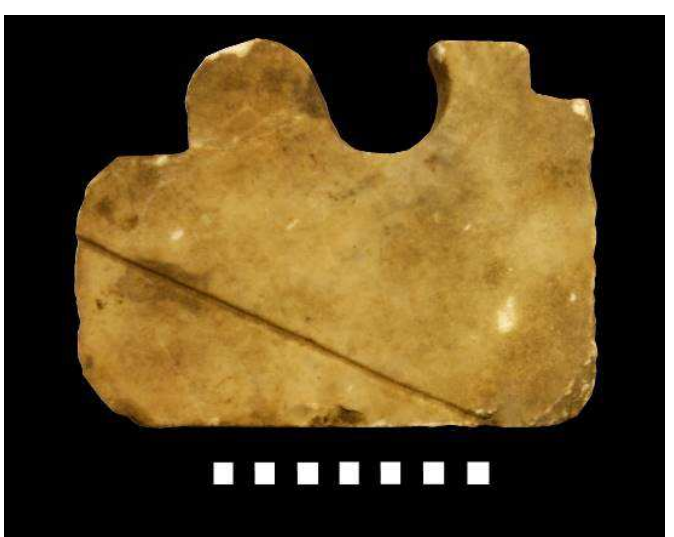

Figure 20. A decorative marble plate.

\section{The Hill}

On September 2011, the firm ATS of the Siena University in commissioned by the CNRS laboratory of École Normale Supérieure de Paris, conducted the first magnetometric survey over the promontory lying in a dominant position towards the coast, between the Casale Alibrandi and the Via Aurelia. It refers to a wide area measuring $14.000 \mathrm{mq}$. The peak of this promontory it is not so high (only 7,4 $\mathrm{mt}$ s.l.m). The whole area had been abandoned and left uncultivated for several years. On this area just today the building activity is blocked because of the archaeological restrictions covering more and less the whole area corresponding to the ancient city of Castrum Novum.

The result of the geomagnetic investigations, has allowed to identify a regular urban plane North-West to South-East oriented with several building traces (Fig. 21). It seems possible to recognize numerous spaces of different dimension, at least a long rectilinear wall and several traces of other construction that defined almost a perfect rectangle measuring $100 \times 70$. It represents only a hypothesis, but the traces we have above described could correspond to the rest of the republican wall and so to the ancient castrum of $3^{\text {rd }}$ century $\mathrm{BC}$, over which, the imperial settlement will be developed.

Today, within this area, it is possible to observe the presence of several ruins emerging from the ground. It is possible to notice the presence of several structures built in opus reticulatum, which seem to lie below the current ground level. These structures, kept to, at least, one meter high, show the use and frequentation of this area since the $3^{\text {rd }}$ century $\mathrm{BC}$ to the $5^{\text {th }}$ century AD.

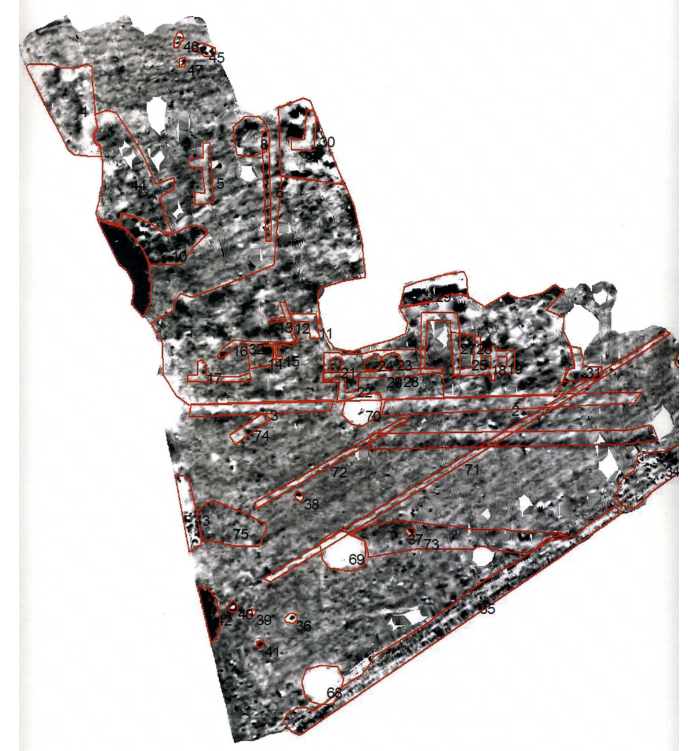

Figure 21. In this figure (magnetic map), it is possible to notice the anomalies on the Hill and some squared structures.

The survey over this area restored numerous archaeological materials among which we can signal the presence of republican and imperial amphorae fragments, black varnish ware, italian sigillata and late-italian sigillata, African ware (A,C and D), African cooking pottery and dolia. We must add to this list the finding of numerous building materials, mosaic tesserae and marble fragments.

\subsection{Statues and Epigraphs from Castrum Novum to the Vatican Museum}

Under the pontificate Pius VI began a significant acquisition of several masterpieces whether through the antiques market or through the confiscation of fortuitous finding and the organization of archaeological campaigns to improve the exhibition of the early Vatican Museums. One of 
these campaigns was carried out on the ancient site of Castrum Novum, at that time a Reverenda Camera Apostolica's property. Through the years, on this site four digs occurred, from which came six statues, nine inscriptions and two massive tables. Today, these artifacts adorn the halls of the Pio Clementino Museum and the Lapidarium. During the excavation supervised by Giovanni Corradi, numerous of these findings came from the area called Torre Chiaruccia. Giambattista Visconti (Superintendent of Antiquities of Rome), which elaborated a list, although it contains different mistakes [29] identified these sculptures. All these pieces, show a great value as, for example, the statue of Priapus, the Aspasia's herm, the statue of a mastiff dog, the little statue of Baccus, and others pieces: in fact, if we carefully analyze them, they can provide important information, about the customs and tradition of the site. About the statue of Priapus (the rustic god of the bounty, the protector of the sheep, goats, bees, vine and all garden products) it is likely that it is a copy of the Hadrian Age: its marble, quite dull and cold, reveals a coarse work. (Fig. 22).
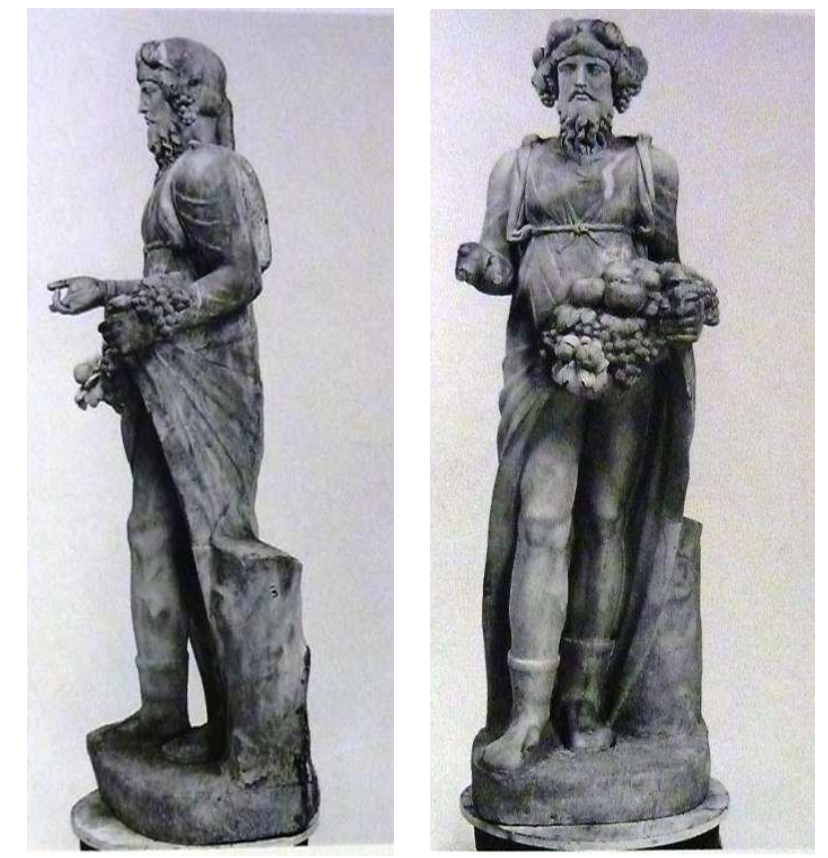

Figure 22. Priapo statue. From the dig of the 1778 at Torre Chiaruccia (Castrum Novum). Museo Pio Clementino. Cortile Ottagono del Belvedere. Hermes' Cabinet. Hadrian Age.

However, it evokes an original Greek piece by the Lysippos school (Silenus with the little Dionysus, 300-280 BC) with the difference that in this case the statue has a comic value [29] [30] (Fig. 23). Thanks to Nibby, we know about the arrive in Castrum Novum of habitants from (probably) Castrum Inui, a village which had been abandoned, founded by Latino Silvio and located between Anzio and Ardea [31] These people, coming to Castrum Novum, should have carried with them the Priapo's cult. In fact, Inuus, is also the ancient name of this god. Probably, the only one function of this statue might have been decorative [32]. Another important piece is represented by the marble herm of Aspasia, which presents the inscription of its name on the base. Discovered in 1777, it is considered, by some scholars, a copy of the relief placed on the grave of the woman loved by Pericles. She was a cosmopolitan, cultured, wise woman, very different by the others Greek women of her time. It goes back to the first half of the $2^{\text {nd }}$ century $\mathrm{AD}$, but it is a copy of a more ancient statue dated to the $5^{\text {th }}$ century $\mathrm{BC}$, which could have undergone some modification by the $4^{\text {th }}$ century hairstyle (the so-called melon coiffure) [29]-[33]-[34]. The iconography remembers the bronze statue of Afrodite Sosandra (470-460 BC), produced by Calamide, the best artist with this metal, of the Severe Style [35] (Fig. 24).

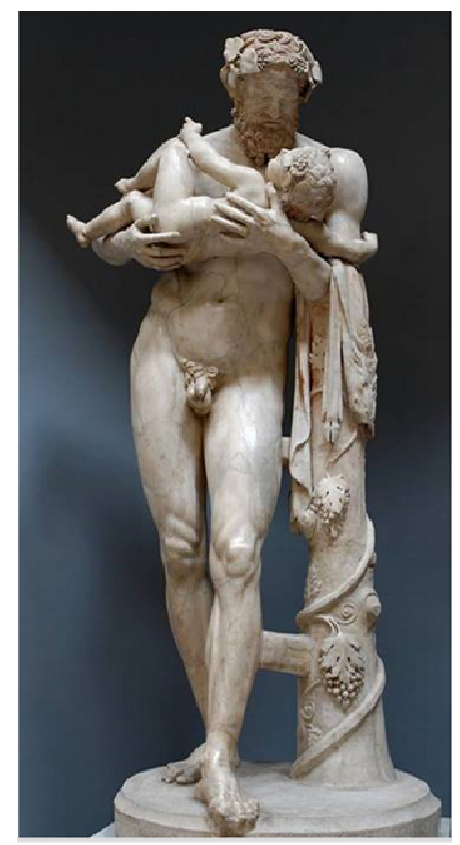

Figure 23. Silenus with Child Dionysus. Roman Copy of Greek Original By the School Of Lysippus (C. 300 BC). Vatican Museums.
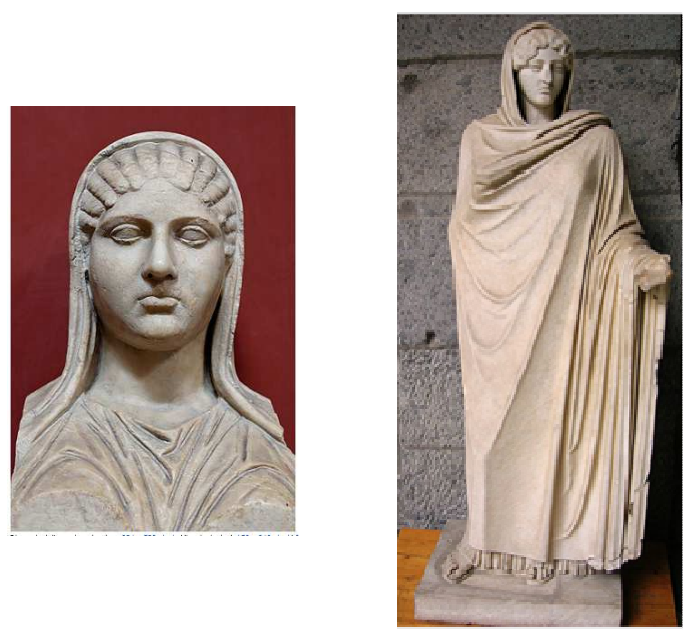

Figure 24. Aspasia Herm, from the escavations near Torre Chiaruccia in the 1777. First half of the $2^{\text {nd }}$ Century AD. Museo Pio Clementino - Sala delle Muse. On the right the statue of Afrodite Sosandra.

Other important data came from the epigraphs. They are 
about sixteen and through them we can understand some aspects of the municipal life, the economy, the society and the lifestyle of the colony from the $1^{\text {st }} \mathrm{BC}$ to the $3^{\text {rd }}$ century $\mathrm{AD}$. The most significant of these are relating to the instrumenta: public document from which we can extract the names of the owners of the houses or villae of the colony. Particularly, we point out the name of Ulpiano, one of the most important jurist of the Antiquity and chief adviser of Alessandro Severo. Moreover, from these inscriptions came the names of artisans, manufacturers of tiles and clay objects, such as Marcus Galicius Diophantus, name inscribed on a dolium, or even that one of Domiti (Gemini) on a tile [36]. Thanks to the funerary inscriptions, it is possible to understand, although in general terms, whether the social structure of the Castrum Novum's population or some biographical information, such as the names, the age and profession of some citizens. Through other inscriptions we can also deduce the religious worship here practiced, such as the cult of Apollo, whose name is linked to the reconstruction of a bridge, known as the pons Apollinis by Septimio Severo and Caracalla [37] (Fig. 25).

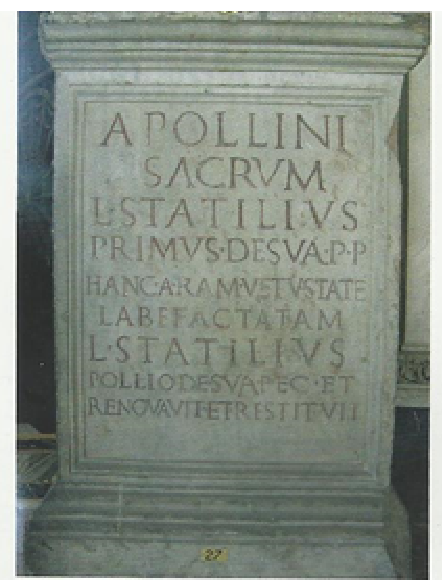

Figure 25. Inscription to Apollo by Lucius Statilius Primus. Rome. Vatican Museum

Several names of celebrities and members of high social class, found engraved on the stone, inform us that they had chosen Castrum Novum as own residence. At these stone fragments were relied more different posts: a special occasion, a dedication, a memorial, a prayer, a law [6]. Therefore, we can consider them an useful and interesting way to connect with the ancient world, in order to be able to communicate with the Ancient and read their messages. Thanks to the analysis of these epigraphies and statues, it was possible to become aware about determinate aspects of the life of this site.

\section{The Roman Harbor}

Through the centuries, the bay corresponding to the ancient harbor of Castrum Novum suffered numerous erosion activities by the sea. The consequence of this was the transformation of the coast trend, the collapse and the submerging of numerous ancient structures lying along the coast (Fig. 26). Some ruins in this area had been pointed out since the $18^{\text {th }}$ century then documented by Piero Alfredo Gianfrotta within his work [5]. With the new international project has been realized the survey of the structures and the systematic study which will lead to the reconstruction of the ancient coastline by the Group of M.S.C. (Marittime Study Center). Along the stratigraphic section, caused by the sea erosion, longer than 150 meters, it is possible to recognize several Roman Imperial structures belonging to some house's spaces, a balneum with mosaic decoration, plaster painted and marble covering. We can especially recognize the ruins of a big semicircular structure with lateral ducts, probably belonging to another balneum actually destroyed and submerged by the sea [6].

Several sewer pipes and Roman walls remains are visible along the height difference coast between the current ground level and the beach. Most of the numerous archaeological materials found here can be dated between the $3^{\text {rd }}-2^{\text {nd }}$ century $\mathrm{BC}$ and the $4^{\text {th }}-5^{\text {th }}$ century AD. In some case, we can observe that the Roman structures cut the previous stratigraphy belonging to the Bronze Age or the Iron Age. With regard to the Iron Age findings, we can signal the traces of an Iron Age floor belonging to a hut [4].

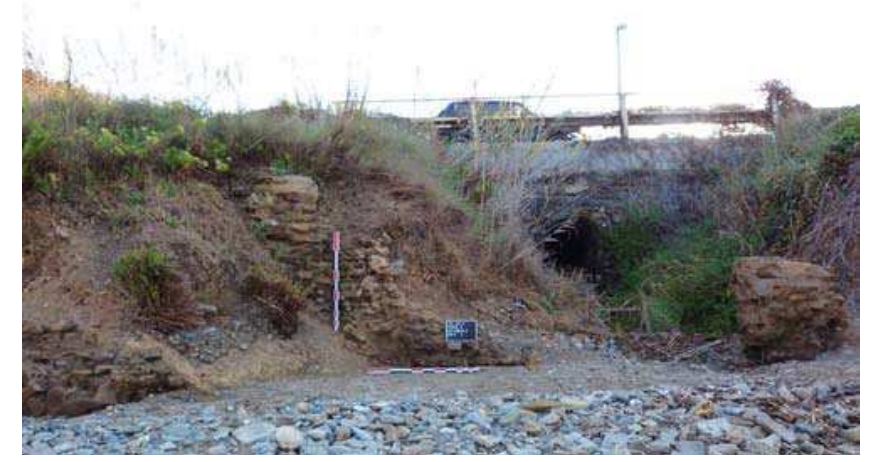

Figure 26. Terracing wall No. 17.

\subsection{Pottery from the Sea Bottom}

The Maritime Study Center of Santa Marinella has developed the underwater archaeological research, occurred during the latest years into the bay of Castrum Novum. The bay, which corresponds to the ancient port of Castrum Novum, lies from Capo Linaro to the moat of Guardiole.

Several findings have taken place both along the beach and from the sea bottom where archaeological material lied just in a depth about 10 meters. It is interesting that, except some case of sea encrustation, the archaeological material here discovered seems to be well preserved. In confirmation to the archaeological report from the Zone A (balneum and squared building), also in this case the presence of black varnish ware seems well attested by two pieces very well kept, such as a half preserved cup with double rod-shaped handles, type Morel $3131 \mathrm{~b} 1$, dated to the $2^{\text {nd }}$ century BC, and part of a cup belonging to the type Morel 2323 dated to the first half of $2^{\text {nd }}$ century BC. A third piece of black varnish ware not so 
well-preserved corresponds to a bottom of a cup with ring base comparable with a form generically dated to the $3^{\text {rd }}$ century BC [28].

The terra sigillata is represented here by three finds, two of them in a well preserved status for at least the half of their original shape. These three finds actually represent the most interesting features for their typology and origin.

The first one corresponds to a fragment of cup of south-gallic terra sigillata cup, comparable with the type Dragendorff 36 dated to the $1^{\text {st }}-2^{\text {nd }}$ century AD [38].

The second piece belongs to the class of north-italic terra sigillata which seems comparable with the type Dragendroff $24 / 25$ type A, going back to the first half of $1^{\text {st }}$ century BC [38] (Fig. 27). An aretine terra sigillata ring base with a stamp inside it, impossible to be read, represent the less-preserved find. Other fragments here found belong to the coarse ware generally dated to the $2^{\text {nd }}-1^{\text {st }}$ century BC.

Outside of the pottery context, it is interesting to point out a marble find, probably a little antefix with a palm decoration, found along the beach (Fig. 28).

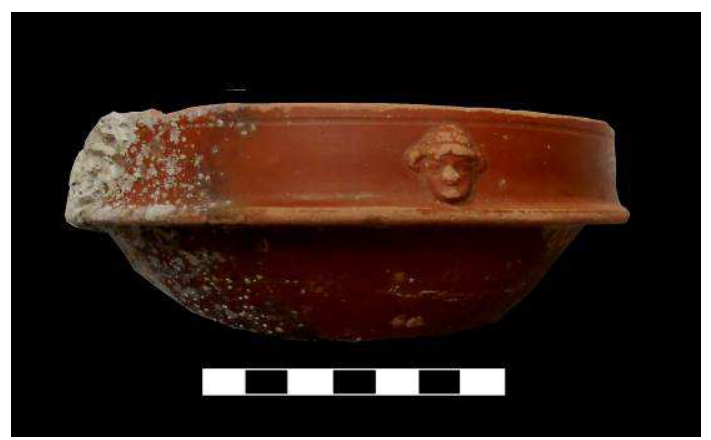

Figure 27. North-Italic terra sigillata

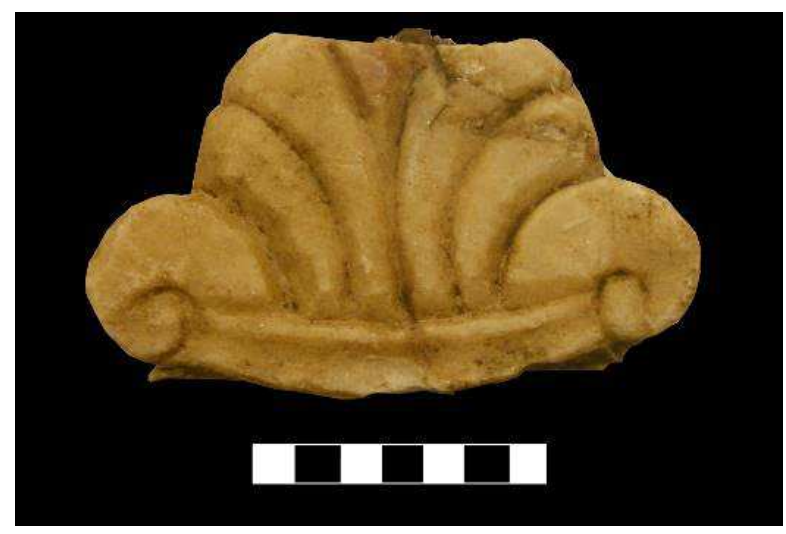

Figure 28. Marble antefix

\section{Conclusion}

Among the years 2010-2014, the archaeological campaigns in Castrum Novum have brought to light a big amount of data, which promised to increase with the early excavation of the hill where the rest of the ancient city should have been buried. In fact, right now the archaeological campaigns are concentrated on the ruins belonging to a balneum and a building, probably identified as a domus that underwent several modifications through the centuries.

These modifications could be interpreted as the consequence of a different use than that one of a house, such as a mansio or a mutatio, an official stopping place on a Roman road. However, the finding of important archaeological materials into the space corresponding to the portico could indicate the presence of trade activities linked to the selling of fish. The wide interior, lying along the northern wall, could have been used as deposit or storage, stable, cowshed or several work activities. The position of the squared building, facing on the street, and its plan so similar to that one of a domus with entrance halls, seems to indicate a different use of this building, surely not used as a farm. It is possible that, at least between the $1^{\text {st }}$ and $2^{\text {nd }}$ century $A D$, the building had been modified in a caupona at least once before its abandon; it could have been a pub where it was possible to find fish or maybe a little hotel with the balneum.

Certainly, it should have represented an ideal opportunity to a temporary shelter for the wayfarers transiting from and towards Centumcellae. On the balneum it was possible to set a study about the masonries. The archaeological layers, the wall structures and the brick stamps' analysis together with the study of the archaeological material here found, suggest the evidence of several stages of life and more transformations of these structures between the $1^{\text {st }}$ and the $3^{\text {rd }}$ century AD. The lucky finding of a lead tube (fistula aquaria) with the inscription of Marcus Clodius Lunensis, consul suffectus on $105 \mathrm{AD}$, suggests us that he could be a possible owner of this bath, probably a rich and important dominus belonging to the senate rank. It seems also possible that he was the owner of both structures the balneum and the villa, during the Trajan age, between the end of 1 st century and the beginning of $2^{\text {nd }}$ century AD.

\section{Acknowledgements}

Thanks to Dr. Antonia Amoroso for the translation and supervision of this paper.

\section{References}

[1] Rut. Nam, De reditu Suo, Einaudi I, 231-232, 1992.

[2] PH. Cluverius, Italia Antiqua, II, Legduni Batavorum, 1624.

[3] A. Bonneau, Les Confessions de Jean-Jacques Bouchard, parisien, suivies de son voyage de Paris à Rome en 1630, publiés pour la premiére fois sur le ms de l'auteur, Paris 1881 .

[4] F. Enei, M. L. Haack, S. Nardi Combescure, G. Poccardi, Castrum Novum. Storia e archeologia di una colonia romana nel territorio di Santa Marinella, Quaderno I, Santa Marinella 2011.

[5] P.A. Gianfrotta, Castrum Novum, Forma Italiae, regio VII volumen Tertium, Roma 1972.

[6] F. Enei, S. Nardi Combescure, G. Poccardi, Castrum Novum. Storia e archeologia di una colonia romana nel territorio di Santa Marinella, Quaderno 2, Acquapendente (VT) 2013 
[7] Martorelli, Le strutture murarie di epoca altomedievale delle chiese di S. Stefano ad Anguillara Sabazia e di S. Liberato a Bracciano: analisi stratigrafica, in Antichità tardoromane e medievali nel territorio di Bracciano (Bracciano- castello Odescalchi 15 giugno 1991), Viterbo 1994, pp. 67-96

[8] G. Volpe, Villaggi e insediamento sparso in Italia meridionale fra tardo antico e alto medioevo: alcune note, in G.P. Brogiolo, A. Chavarria Arnau, M. Valenti (a cura di), Dopo la fine delle ville: le campagne dal VI al IX secolo, Documenti di Archeologia 40, Mantova 2005, pp.221-249

[9] V. Fiocchi Nicolai, I cimiteri paleocristiani del Lazio, I, Etruria Meridionale, Città del Vaticano 1988

[10] F. Marazzi, Il Patrimonium Tusciae della Chiesa romana tra VI e X secolo: note sulle sue pertinenze fondiarie in T.W. PotterA.C. King, Excavations at the Mola di Monte Gelato. A roman and medieval settlement in South Etruria, Archaeological Monographs of the British School at Rome, 11, Roma 1997 ,pp. 412-420

[11] S. Del Lungo, Insediamenti della bassa Valle del Marta nella tarda antichità e nell'altomedioevo (secoli V-IX) in Bollettino della Società Tarquiniense di Arte e Storia, XXVIII, 1999, pp.23-73

[12] G. Olcese, Ceramiche comuni a Roma e in area romana: produzione, circolazione e tecnologia: tarda età repubblicanaprima età imperiale, Mantova 2003

[13] S. Tortorella, Ceramica Africana, Ceramica da cucina, in Enciclopedia dell'Arte Antica, Atlante delle forme Ceramiche, I, Roma 1981, pp. 208-224 Pavolini

[14] C. Pavolini, Appunti sui vasetti ovoidi e piriformi di Ostia, in Melanges de l'École Française de Rome. Antiquitè, T.92, n.2, 1980 , pp. 993 - 1020; doi: 10.3406/mefr.1980.1260 http://persee.fr/web/revues/home/prescript/article/mefr_02235102_1980_num_92_2_1260

[15] A. Buonopane, medico in un'iscrizione inedita della Cisalpina in Sylloge Epigraphica Barcinonensis (SEBarc), IX,2011, pp.123-129

[16] E. Rodriguez Almeida, Sobre el uso del anforisco Cucurbitula in Melanges de L'Ecole Française de Rome. Antiquitè, T. 86, n. 2, 1974, pp. 813-818; doi: 103406/mefr.1974.990 http://persee.fr/web/revues/home/prescript/article/mefr_02235102_1974_num_86_2_990

[17] G. Disantarosa, Le anfore: indicatori archeologici di produzione, delle rotte commerciali e del reimpiego nel mondo antico, in Classica et Christiana, 4/1, 2009, pp. 119-232

[18] E.A. Arslan, Osservazioni sull'impiego e la diffusione delle volte sottiliin tubi fittili, in Bollettino d'Arte, I-II,1965, pp. $45-52$

[19] C. Pavolini, Scavi di Ostia. La ceramica comune. Le forme in argilla depurata dell'Antiquarium, XIII, Roma 2000
[20] C. Isings, Roman Glass from Dated Finds, Groningen -Djakarta 1957

[21] G.L. Ravagnan, Vetri antichi nel Museo vetrario di Murano. Collezioni dello Stato, Murano- Venezia 1994

[22] M. Calvi, I vetri romani del Museo Archeologico di Aquileia, Aquileia 1968

[23] C. Maccabruni, I vetri romani dei Musei Civici di Pavia: lettura di una collezione, Pavia 1983

[24] D. Lissia, E. Zanda, Museo Archeologico di Asti. La collezione dei vetri, Torino 1994

[25] A. Toniolo, Vetri antichi del Museo Archeologico Nazionale di Este, Venezia 2000

[26] G. De Tommaso, Ampullae vitrea: Contenitori in vetro di unguenti e sostanze aromatiche dell'Italia Romana (I sec. a.C. -III sec. d. C.), Roma 1990

[27] L. Crema, L'architettura Romana, in Enciclopedia Classica, sezione III, Archeololgia e Storia dell'Arte Classica, XII, I, Torino 1959

[28] J. P. Morel, Céramique campanienne: les formes, I-II, Roma 1981

[29] C. Pietrangeli, Scavi e scoperte di antichità sotto il pontificato di Pio VI, 2 ed, Roma 1958

[30] W. Amelung, Die Skulpturen des Vaticanischen Museums, II, Berlin 1908

[31] A. Nibby, Analisi storico-topografica - antiquaria della carta de’ Dintorni di Roma, Roma 1837.

[32] E. Paribeni, Priapo, in Enciclopedia dell'Arte Antica, classica e orientale , Roma 1965, pp.466-467

[33] G. Lippold, Die Skulpturen des Vaticanischen Museums, III, Berlin und Leipzig 1936

[34] W. Helbig, Guide to the public collections of classical antiquites in Rome, I, Leipsic 1895

[35] P. Orlandini, Kalamis, in Enciclopedia dell'Arte antca, classica e orientale, Roma 1965

[36] S. Bastianelli, Centumcellae - Castrum Novum: Regio VII, Etruria: Italia romana, municipi e colonie. Serie 1, XIV, Roma 1954

[37] Corpus Inscriptionum Latinarum, XI 3574

[38] A. Carandini (a cura di), Atlante delle forme ceramiche, ceramica fine romana nel bacino Mediterraneo, vol. II, suppl. EAA, Roma 1981. 